\title{
Enhancing the traditional Mediterranean irrigation agroecosystems: a case study of the rivers Túria and Júcar (Valencia, Spain)
}

\author{
I. Martínez-Sanchis \& M. J. Viñals \\ Universitat Politècnica de València, Spain
}

\begin{abstract}
Since ancient times, agriculture has had a significant impact on ecosystems in the Mediterranean basin. Current cultural landscapes are a result of these historical activities and they are sites where traditional human knowledge is reflected in both tangible and intangible heritage assets.

The use of water for agriculture has always involved an understanding of the geographic space, hydrology management practices, and the engineering design of hydraulic devices such as small dams, weirs, irrigation channels, pools, or water mills, among other things. The intangible heritage is also especially relevant since the historical irrigation system provides the landscape with a structure characterized by orality, best practices, and traditional environmental knowledge.

However, this heritage is at risk due to its wide territorial spread and in some cases loss of functionality. Urbanization, unsuitable land usage and loss of production are also factors that can be mentioned.

This paper focuses on analysing the influence that the tangible and intangible heritage and the landscapes linked to the Rivers Júcar and Túria have on local development. The results indicate the existence of several resources with great cultural and recreational potential. They also continue to be key elements in the functioning of existing historical irrigation systems and, for this reason, these irrigation systems can still be considered fundamental drivers of the current sustainable development.
\end{abstract}

Keywords: territorial management, cultural landscape, hydraulic heritage, traditional irrigation system. 


\section{Introduction and objectives}

The Mediterranean basin is a semi-arid climate region where water resources are limited and irregular in both time and space. Therefore, historically, the freshwater ecosystems have been subjected to intense pressures from humans. In this context, the water management of the fluvial ecosystems, in all its intricacies (adaptations to the topography, geology, hydrology, climate, and biota), was the basis of agriculture, which gave way to farmed landscapes (agroecosystems) as a result of centuries of sustainable interaction between people and nature.

These traditional land use systems are still operational ('active living landscapes') and continue to provide valuable economic input. Moreover, nowadays, they are also considered cultural assets because of their historical features (archaeology, traditional buildings, distinctive settlements, local customs, and traditions) and the existence of intangible asset like Local Traditional Ecological Knowledge (TEK), also referred to as Local Ecological Knowledge (LEK), indigenous knowledge or ecoliteracy, that, according to Berkes [1] can provide lessons and insights in addressing the relationships between humans and nature. These systems are called 'Cultural Landscapes' and the UNESCO World Heritage Convention [2] defines them as "the combined works of nature and humankind, that express a long and intimate relationship between peoples and their natural environment". They often reflect specific techniques of sustainable land-use, taking into account the characteristics and limits of the natural environment they are established in. At the present time, 88 cultural landscapes are inscribed on the World Heritage List. The group of water management ecosystems includes the outstanding examples of the ancient Dujiangyan Irrigation System (China) constructed around $256 \mathrm{BC}$ and still in use; the Shushtar Historical Hydraulic System (Iran), from the 5th century BC; the Canal du Midi (France), built between 1667 and 1694, which links the Mediterranean and the Atlantic ocean through 328 structures, and is one of the most remarkable feats of civil engineering in modern times. In Spain some age-old traditional irrigators' communities, such is the case of Hombres Buenos de Murcia (River Segura) and the Tribunal de las Aguas de Valencia (Valencia Water Court), which is studied in this paper.

The FAO has also approached this issue in order to safeguard and support these cultural heritage systems. Thus, in 2002 it started an initiative for the dynamic conservation of Globally Important Agricultural Heritage Systems (GIAHS) that promotes public understanding, awareness, and national and international recognition of these landscapes. Additionally, the European Landscape Convention, also known as the Florence Convention, recognizes the intimate and complex interrelationship between the natural and cultural heritage and the contribution of landscapes to European cultural heritage. This Convention highlights the contribution of the cultural landscapes to the consolidation of the European collective identity and sense of place.

Traditional Mediterranean land-use systems, which as proposed by Mata and Fernández [3] include historical irrigation systems, are a good example of these social-ecological systems with a high conservation value and high cultural 
diversity [4], where traditional management practices were part of an intermediate disturbance regime that has proven to enhance biodiversity [5].

In the framework of these cultural landscapes, the living farmed landscape category includes the 'traditional irrigation system landscapes' that are the focus of this paper. According to Leibundgut [6], the term 'traditional irrigation' implies the technical and organizational management of irrigation as practised in Europe before the introduction of modern techniques (sprinkling, drip irrigation) and the abandoning of old organizational structures (associations, common property regimes). Thus, it can be said that these traditional irrigation systems are derived from social and ecological systems that are interlinked and form complex socialecological systems that co-evolve over time [7].

Historical water uses for agriculture involve an understanding of the geographic space, hydrology management practices, and engineering design of hydraulic devices. The intangible heritage is, as mentioned, also especially relevant since the historical irrigation system provides the landscape with a structure characterized by orality, best practices and traditional environmental knowledge.

Fluvial ecosystems have historically worked in agriculture. As a result of such activities, these traditional irrigation systems reflect tangible and intangible assets that endow the rural landscape with personality and identity and represent a valuable cultural heritage.

Leibundgut and Kohn [8] have listed at least 60 potential sites of traditional irrigation systems in Europe which deserve integral preservation. This list includes the Spanish Traditional Irrigation systems of the Valencian Rivers Túria and Júcar, studied in this paper, although they have not yet received official recognition. Only the River Túria partially enjoys the status of regional natural park (Parc Natural del Túria), and its intangible management structure (Valencia Water Court) is listed in the UNESCO World Heritage Convention as an intangible asset, as mentioned above. Therefore, this work intends to understand, appreciate and enhance the significance, as heritage elements, of the structures and features used in water management in these floodplain rivers in order to raise awareness about the need to preserve and protect them. This is important because there remain few traditional irrigation systems still in operation in Europe and without a prompt institutional response in just a few years it may be too late. Moreover, these traditional systems can be considered to be "learning laboratories" because they have resulted from advanced knowledge about sustainable techniques in land use. Additionally, protection of these traditional cultural landscapes can maintain or enhance natural values and biodiversity in the Mediterranean fluvial region.

Lastly, as Sabaté [9] points out, the new approach of the concept of territorial planning in the 21 st century is focused on the nature-culture basis and that fits in perfectly with the idea of cultural landscape.

First, this paper presents a general overview of these two traditional Valencian irrigation systems (Fig. 1). It will then carry out a heritage assessment of the tangible and intangible landscape components. Finally, the paper proposes a legal framework of regional protection aimed at the conservation of this rich legacy, so 
that users, managers, local authorities, and Valencians in general can become aware of how to manage environmental assets in the pursuit of the common interest.
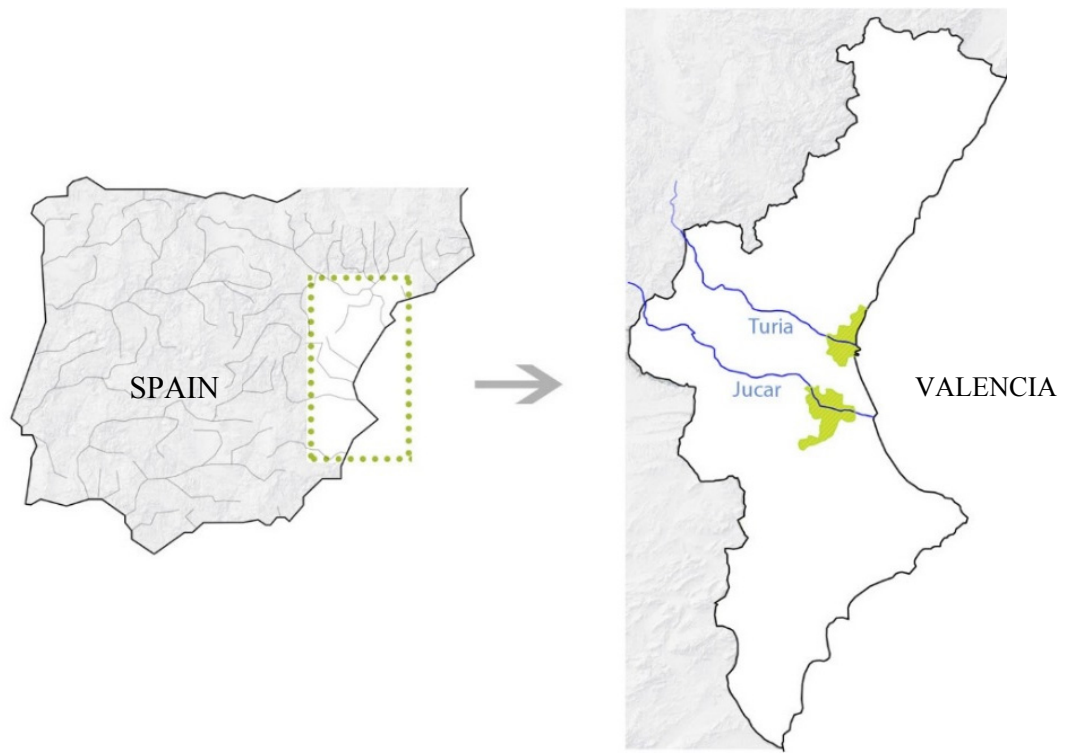

Figure 1: Location of the Rivers Túria and Júcar and their traditional water meadows.

\section{Traditional Túria and Júcar irrigation systems}

A large body of scientific literature and debate exist regarding the origin of the traditional Mediterranean irrigation systems in Spain [10]. It is well known that the Romans extended the agricultural legacy throughout the Spanish provinces, as proven by archaeological remains [11], and during the Andalusi period (9th-13th centuries) the irrigation system was intensified with a new territorial organization, which created a network of irrigation channels that allowed the wise use of water over an extensive area $[12,13]$. After this, the Christians (13th-15th centuries) expanded and consolidated this legacy. Subsequent events, such as the discovery of America and the financing of waterworks by the bourgeoisie and by the monarchy, marked the arrival of new crops and increased production by encouraging the expansion of these traditional irrigation systems.

The irrigation systems analysed here are located in the Valencian region, in the downstream floodplains of the Rivers Túria (Fig. 2) and Júcar, just before they flow into the Mediterranean Sea.

Over the centuries, water management in these floodplains has yielded a wide range of heritage elements, which can be divided into three types: tangible assets directly linked to the hydraulic constructions, intangible heritage related to the 


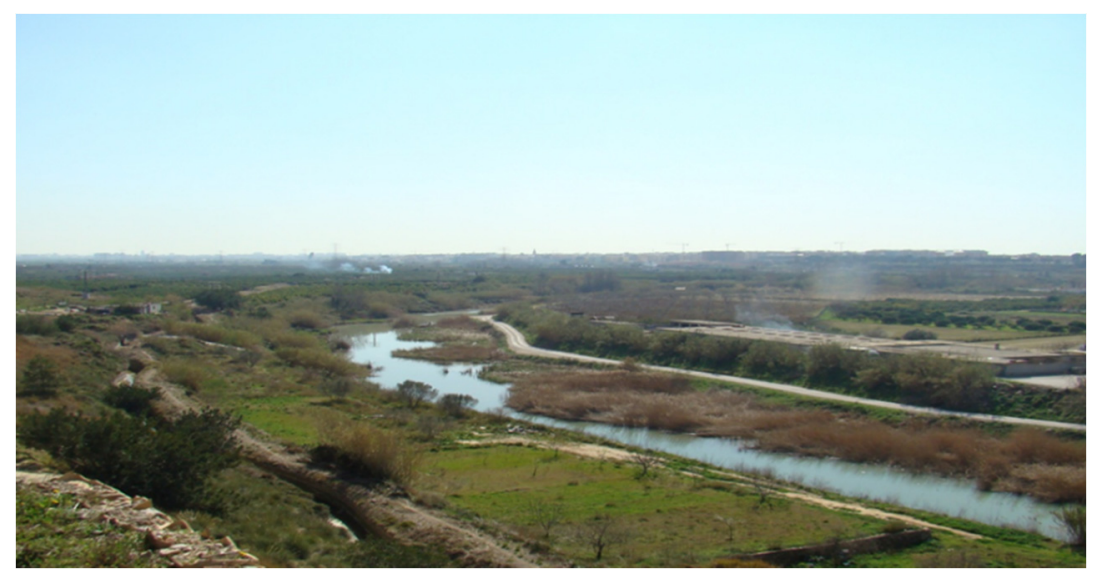

Figure 2: River Túria floodplain in the borough of Manises (Valencia).

legal, technical and administrative organizations and structures used in the irrigation assimilated to the concept of TEK, and traditional agroecosystem landscapes such as the water meadow systems. These buildings, engines, knowledge and landscapes are part of the history, customs and identity of the community they belong to, but they are also still in operation, being a vital element in the current regional economy.

From the hydraulic inventory carried out by Hermosilla [14], it can be noted that the main hydraulic heritage elements found in these water meadow systems are: engines for water distribution such as irrigation ditches and channels of different sizes, but also dams, weirs (Fig. 3), wells, reservoirs and ponds, waterwheels, watermills, gauge stations, small floodgate chambers, water dividers, bridges and public washing places. Some of them have individually achieved national or local legal recognition (Bien de Interés Cultural-BIC, Bien de Relevancia Local - BRL).

These rivers maintain their traditional organizational water structures: the Valencia Water Court, on the River Túria, and the Acequia Real del Júcar Irrigation Community, on the River Júcar. These traditional irrigation systems are mainly based on an orally-transmitted knowledge of water management techniques, rules and regulations, and social and cultural expressions.

The origin of the Valencia Water Court is unclear, but it most likely dates back to the Andalusí period. The court is composed of eight farmers from the irrigation communities which take their waters from the River Túria (Quart, BenàgerFaitanar, Tormos, Mislata, Mestalla, Favara, Rascanya and Rovella canals). Its jurisdiction is restricted to Valencia's Watered Land district. Specifically, it extends over 3471 hectares with a total of 11,691 members. The Court, acting as an executive body, resolves conflicts between irrigation water-users orally and publically at the gate of Valencia Cathedral every Thursday at noon. This court is included with the Spanish judicial system, with the same guarantees and legal value as any civil court, so that their verdicts cannot be appealed against before ordinary courts [15]. 


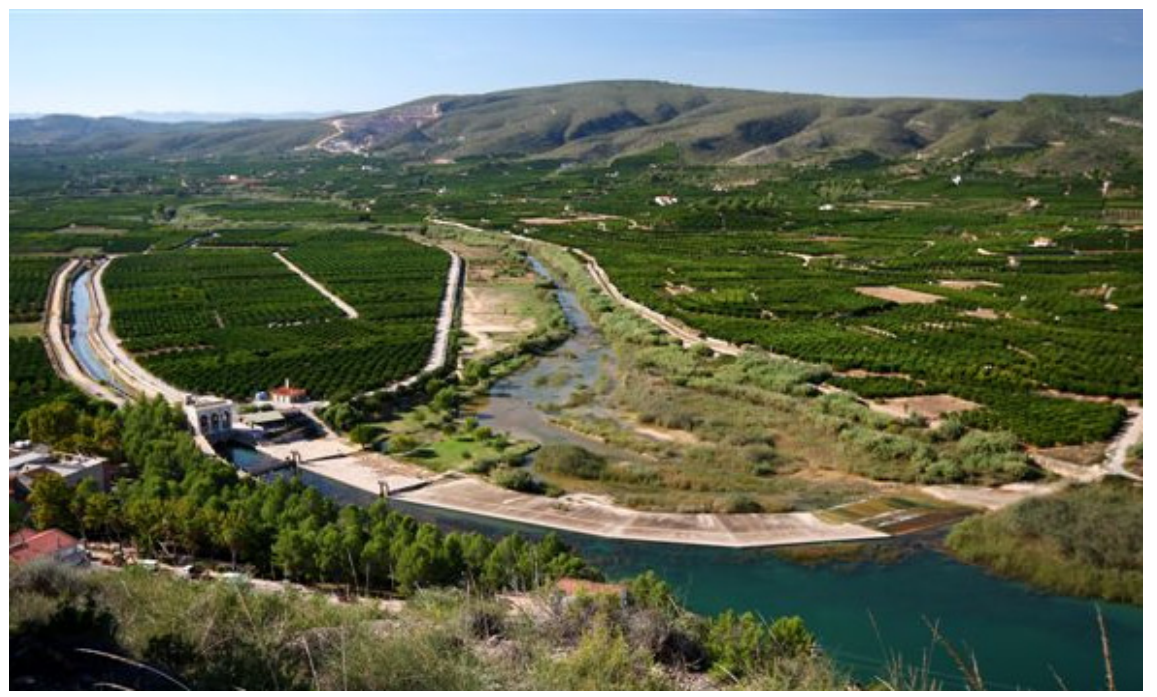

Figure 3: The Antella Weir on the River Júcar.

Moreover, the Acequia Real del Júcar was built by King Jaume I in the 13th century. On completion, its management came under the control of the royal officials, who gradually yielded attributions to the irrigators. In 1350, the Ordenanzas, the first regulations giving executive competencies to the irrigation community, were written. This institution currently consists of ten members who meet monthly to decide on water management and it also has its own local irrigation court to solve conflicts among farmers in a peaceful way.

The other heritage assets linked to these irrigation systems are their interesting cultural landscapes. Hydraulic devices and traditional knowledge of water management interact jointly with the natural environment over time, producing valuable water meadow systems on both rivers. These important agroecosystems are still lacking comprehensive legal protection as cultural assets.

All these tangible and intangible assets and landscape elements are directly related to the history and the identity of the society that has created and inhabited these lands, leaving a cultural print that is reflected in the territorial and social organization and the rich water heritage.

\section{Results and discussion}

The links between traditional irrigation system resources and environment and history have produced a series of strengths that show the values that they had in the past, but which are nowadays not currently known or valued. The increasing interest in the value of the water meadow systems for environmental (green corridors and healthy environment close to the urban areas) and socio-economic purposes (e.g. identity, sense of place, responsible tourism) justifies this kind of analysis. The case of the River Túria green corridor is already in operation [16], 
with more than a million visitors per year after the work carried out on restoration and public use in recent years.

Beyond the intrinsic values held by these traditional irrigation systems of the Túria and the Júcar, another assessment is also possible. By means of an enhancement process, some new actualities can take place in relation to resource and landscape protection, territorial planning, recreational uses and social awareness. In order to carry out an applied assessment of these resources, the following criteria have been selected: integrity, significance, fragility, representativeness, attractiveness, availability, feasibility and accessibility.

Integrity in a traditional irrigation system must be interpreted as a comprehensive set of facts and elements that allow the operational functioning of the system today. Thus, the hydraulic engines, functions, traditions and landscape must be fully preserved and protected.

These traditional irrigation systems can also be considered very significant and unique assets due to their outstanding environmental, historical, cultural and socioeconomic values.

From the point of view of fragility, it may be noted that hydraulic devices are not fragile resources as they have survived to the present day thanks largely to the societies that guarantee their conservation. Nevertheless, the cultural landscape has a medium-high level of fragility and it presents symptoms of degradation on both rivers due to the impacts of actions by humans (e.g. abandoning of traditional activities, depopulation, lack of management and political will).

On the other hand, the traditional irrigation systems analysed here are highly representative and include all the typical attributes of these Mediterranean cultural landscapes.

The attractiveness of these landscapes is based on their scenic, aesthetic, emotional and perceptual features, supported by the intangible values manifested in the traditional ecological knowledge of their inhabitants throughout centuries. Typical Mediterranean gastronomy originating from on-site agriculture production is another value that increases its appeal.

Furthermore, the availability of resources in time and space is large because they are extensive areas enjoying good weather throughout most of the year.

The feasibility of these traditional irrigation systems refers to the enhancement of economic viability (assessment of cost and benefits, restoration costs, management and maintenance costs, as well as social benefits and stakeholder attitudes). The most important costs are those arising from environmental restoration work in certain points on the water meadow land, as well as some hydraulic construction.

There is good access to the assets because many highways and main roads run along the Túria and Júcar fluvial corridors, together with on-site multi-use rural trails. Other recreational facilities such as signage, tourism interpretative routes, and tourism services and transports are also available. 


\section{Concluding remarks}

After the application of these criteria for the recreational enhancement of these agroecosystems, findings highlight a great potential for public use initiatives. However, a problem arises that must be addressed, i.e. the need to legally protect the traditional irrigation systems as a whole under an appropriate category of protection such as 'Cultural Park'. Unfortunately, the Valencian regional laws do not include this category, and the existing ones (BIC, BRL) do not guarantee the appropriate conservation of these properties because no additional management tools are foreseen in these regulations. These assets are considered 'living heritage', as stressed at the beginning of this work, and they are in need of special management. Following Bray [17], the priority for heritage landscapes is not preservation but active cultural resources' management. The figure of 'cultural park' will be very useful not only to protect traditional irrigation systems but also archaeological sites and other cultural properties of a territorial nature which need active conservation.

Additionally, Sabaté and Lista [18], Eugster [19] and Bustamante and Parra [20] agree that smart heritage management is a key factor in economic development for local communities.

These agroecosystems are at risk of disappearance due to urban sprawl over farmlands; visual degradation of the landscape marked by the construction of unsuitable items (e.g. telephone and power lines, non-traditional buildings, hoardings and advertisements); the division or abandonment of the water meadow system and the elements it is comprised of; also the extension of infrastructures such as roads, railways or slopes that act as a rigid barrier; or unsuitable uses such as factories, storage areas and landfills. Additionally, the implementation of new irrigation technologies such as drip irrigation, without entering into the discussion of its advantages and disadvantages, are a threat to traditional irrigation systems, in terms of both their operation and their constructions. Active conservation and protection actions, and policy measures can prevent these threats, and wise public use can enhance the values of these outstanding traditional irrigation systems. They certainly deserve to be included in the UNESCO World Heritage List because of their significance, representativeness, uniqueness, and social values.

\section{References}

[1] Berkes, F., Sacred Ecology. Second Edition, Routledge, New York, 2008.

[2] UNESCO, Operational Guidelines for the Implementation of the World Heritage Convention. UNESCO World Heritage Centre, Paris, 2012.

[3] Mata, R. \& Fernández, S., Paisajes y patrimonio culturales del agua. La salvaguarda del valor patrimonial de los regadíos tradicionales. Scripta Nova. Revista electrónica de Geografía y Ciencias Sociales, vol. XIV, $\mathrm{n}^{\circ}$ 337. Universitat de Barcelona, 2010.

[4] Plieninger, T., Bens, O., Hüttl, R.F., Perspective of bioenergy for agriculture and rural areas, Bioenergy for agriculture and rural areas, vol 35, 2006. 
[5] Blondel, J., Aronson, J., Boudiou JY, \& Boeuf, G., The Mediterranean Basin - biological diversity in space and time. Oxford, UK: Oxford University Press, 2010.

[6] Leibundgut, C., The vision of a cultural heritage of Traditional Irrigation in Europe. 2012. Online: http://www.intwater.uni-freiburg.de/areas/irrigation/ patrimoine.

[7] Ostrom, E., A General Framework for Analyzing Sustainability of SocialEcological Systems, Science. 2009. Online: http://www.sciencemag.org/ content/325/5939/419.

[8] Leibundgut Ch., \& Kohn, I., L'irrigation traditionelle dans le context européen. Evolution-diffusion-fonctions-avernir. Annales Valaisannes, 2010-2011, SCHVR, Martigny, 2011.

[9] Sabaté J., Paisajes culturales. El patrimonio como recurso básico para un nuevo modelo de desarrollo, Urban 9, 2004. Online: http://dialnet. unirioja.es/servlet/articulo? codigo $=2850736$.

[10] Marco, J.B., \& Sanchis, C., Una aproximación a la evolución de los regadíos valencianos. Infraestructura, hidrología e hidráulica. El patrimonio histórico de la Ingeniería Civil en la Comunidad Valenciana, Colegio de Ingenieros de Caminos, Canales y puertos de la Comunidad Valenciana, Valencia, 2003.

[11] López Medina, $\mathrm{M}^{\mathrm{a}} \mathrm{J}$., El agua en el suroeste peninsular durante época romana. Su aprovechamiento para la agricultura, Agricultura y regadío en al-Andalús. Síntesis y problemas. Actas del coloqui. Instituto de Estudios Almerienses, Almeria, 1995.

[12] Alvarez, $\mathrm{M}^{\mathrm{a}}$ A., \& Guerrero, $\mathrm{M}^{\mathrm{a}} \mathrm{D}$., Tradición foral o control oligárquico: Las disputas en torno a la elección de los alcaldes de las aguas en baza (siglo XVI), Agricultura y regadío en al-Andalus. Síntesis y problemas. Actas del Coloquio, Instituto de estudios Almerienses, Almeria, 1995.

[13] Hermosilla, J. (Dir.), Los regadíos Históricos Españoles: paisajes culturales, paisajes sostenibles. Colección Gestión tradicional del agua, patrimonio culturla y sostenibilidad, Ministerio de Medio Ambiente y Medio Rural y Marino, Madrid, 2010.

[14] Hermosilla, J., (Dir.) Las Riberas del Xúquer: Paisajes y Patrimonio Valencianos. Colección de Regadíos Históricos Valencianos, $\mathrm{n}^{\circ} 7$, Dirección General de Patrimonio Cultural Valencià, Generalitat Valenciana, Valencia, 2006.

[15] UNESCO, List of intangible cultural heritage of Humanity, Irrigators' Tribunals of the Spanish Mediterranean coast: the Council of Wise Men of the plain of Murcia and the Water Tribunal of the plain of Valencia. Fourth Session of the Intergovernmental Committee (4.COM) - Abu Dhabi, United Arab Emirates, 28 September to 2 October 2009.

[16] M.J. Viñals; M. Morant; P. Alonso-Monasterio (2012): Connecting urban and rural areas through a green corridor. Case study of the Parc Fluvial del Túria (Valencia, Spain). In Research Studies on Tourism and Environment (ISBN 978-1-61209-946-0). Ed. Nova Science Publishers (New York), pp. 313-324. 
54 Ecosystems and Sustainable Development X

[17] Bray, P.M., The national heritage areas phenomenon: where it is coming from. Coming Resource Management, 17(8), 34, 1994.

[18] Sabaté J., \& Lista, A., Casos d'estudi europeus. Projectant l'eix del Llobregat. Paisatge cultural i desenvolupament regional. Universitat Politècnica de Catalunya-Massachusetts Institute of Technology, Barcelona, 2001.

[19] Eugster, J.G., Evolution of the heritage areas movement. The George Wright Forum, 20(2), 50-59, 2003.

[20] Bustamante, L., \& Parra, C., Paisajes Culturales: El parquet patrimonial como instrument de revalorización y revitalización del territorio. Cultural Landscapes: The heritage park as instrument of Revaluation and revitalization of the territory. Theoria, vol 13, 2004. 